\title{
Issues and Countermeasures of Online Group-Purchasing in China
}

\author{
LIAO Gen-Wei \\ College of Criminal Justice, East China University of Political Science and Law, Shanghai, 200042
}

\begin{abstract}
With the rapid development of online grouppurchasing in China, thousands of group-purchasing websites have established in recent years. It brings huge convenience for people's daily life. However, the emerging issues and problems that the ratio of closured group-purchasing website to the opening is high, the number of the disputes relevant to group-purchasing is increasing, and the privacy of consumers is difficult to protect for, hinder the development of online group-purchasing. The unclear marketing model, the indifference to internet security, the blocked channels of remedies for breach of contract, and the imperfect supervising and management system, may be the reasons behind that. In order to develop and improve the online group-purchasing, the confidence of customers to online group-purchasing should be fostered, the marketing model of online group-purchasing should be innovated, the laws and regulations related to online group-purchasing should be perfected, and the security technologies about online grouppurchasing should be improved.
\end{abstract}

Index Terms - online group-purchasing, marketing model, supervising and management system, internet security

\section{Currents and issues of online group-purchasing in China}

\subsection{Development of online group-purchasing in China}

Online group-purchasing is a new marketing model by which consumers who desire to buy the same merchandises can join together and negotiate with sellers for big discounts through group-purchasing websites or platforms. This new model originated from the Woot, Texas, USA. And it is not well-known until Andrew D. Mason built the group-purchasing website "Groupon". Groupon recommends only one discounted product every day and each person is limited to purchase only once a day whose revenue comes from the commissions from the sellers according to the trade volume. The win-win mode that the customers get the better price, the merchants the quick turnovers with small profits, the grouppurchasing website a certain number of commissions by gathering the scattered customers whose purchase intention are same or similar to buy large quantities of products via internet, is very popular with customers and merchants in China.

With the effect of online group-purchasing brought by Groupon to China, the first group-purchasing website was set up in 2010, and then thousands of different kinds of grouppurchasing website emerged. And now the online grouppurchasing is involved in industries related to food, clothing, shelter etc, as the scale of group-purchasing is growing bigger and bigger in recent years. According to "report about marketing monitoring data of online group-purchasing, 2013(the first half) ", a joint publication of China research center of e-commerce, Lingtuan and China credibility alliance of group-purchasing website, it shows that up to the end of June,2013, the total number of group purchase websites has reached 62188 in China, among which there are 1548 websites which are still operating, and the trade volume of grouppurchasing market has reached 23.989 billion YUAN in the first half of 2013.

There are three modes in group-purchasing: online group purchasing organized spontaneously by consumers; online group purchasing organized actively by suppliers; online group purchasing from the third party websites. And there are mainly two kinds of group-purchasing websites in China, the independent websites, like Lashou, Meituan, Wowotuan, Manzuowang, and platforms provided by other websites, like self-build platforms by B2C websites such as Taobao's Juhuasuan, Jindong's group-buying platform, and self-build platforms by classified website, like 58's group-buying platform.

\subsection{The issues and problems of online group-purchasing in China}

Try Online group-purchasing brings huge convenience for people's daily life, but the new issues and problems which hinder its development are emerging. Firstly, the ratio of closured group-purchasing website to the opening is high. It is easy to build a website of online group-purchasing, just by renting a computer sever and preparing little money. However, almost all the group-purchasing websites in China have the same or similar marketing model. They sprang up and competed for the limited market resources. With the consumers tend to be more rational, the trade volume by online group-purchasing websites presents downward trend. Lots of these websites made negative growth and eventually bankrupted and have to be closured. In order to occupy the market, the new group-purchasing websites have to operate at a loss to attract customers, which seriously affected the development of the online group-purchasing. Analysts pointed out that the gross margin of group-purchasing is around 10\% to the sales amount, but the operation cost such as advertisement, employment, etc., is up to $40 \%$, which unable to make ends meet. These conditions made the profit of group-purchasing websites declining, and eventually led to the closing of capital injection gates from investors. Data showed that the number of group-purchasing websites is 3909 at the end of December 2011, and 5188 at the time when the websites up to the highest record in history. Data also showed that the number of group-purchasing websites born is up to 6177 and websites closured is up to 3482 at the end of 2012 , 
and the ratio of closured to birth has reached $56 \%$; that at the end of June 2013, the number of group-purchasing websites born is up to 6218 and websites closured is up to 4670 with the ratio of closured to birth up to $75 \%$.

Secondly, disputes relevant to group-purchasing occur constantly. With the blossom of online group-purchasing, disputes among the three sides arise endlessly, including the sellers and customers accusing the websites as well as contract disputes between the websites and the sellers. In 2011, Fan Hailiang, CEO of a famous essential oil producer OLDLAND, decided to take an action against 24quan.com for continue to carry out the contract and pay the loan default after the failure of negotiations. In 2012, JingDong, the well-known shopping website, provided a group-purchasing item"1 YUAN Spring Outing" on its website. However, after more than 1700 consumers had bought this product, JingDong imposed a forced refund on the customers with an excuse that the grouppurchasing information of webpage was a test page. This behavior aroused the anger of the consumer. Five consumers from Shanghai bring a lawsuit to Jinshan district people's court to require Jingdong to fulfill commitments, apology and compensation for losses. Other consumers also organized and paid close attention to the progress of the proceedings through QQ or other forms of communication, which turned the grouppurchasing action into group-lawsuit action. In 2011, 12,003 consumers bought coupons of ice cream DQ from grouppurchasing website Meituan. Then DQ made a statement that they never cooperate on group-purchasing with any third party. This forced Meituan to give notice on its website and present their cooperation contract and prepaid certificate of the bank transfer. The CEO of Meituan alleged that they would resolve the disputes through legal channels.

Thirdly, personal information disclosure issues are serious and prominent. After buying products on the groupbuying site, consumers are always required to input lots of personal information, such as phone number, home address, bank card number, etc. If the website can't protect consumers' personal information, it will result in disclosure of personal privacy, which may bring unnecessary trouble and loss to consumers. For example, in August 2013, thousands of members' information appeared on the homepage of "Youth League Committee Group-Buying Website", including name, phone number, goods purchased etc. Although the website has made an emergency deletion, it still brings a psychological shadow to the consumers in their future consumption. In addition, customers' consumption habits, consumption content, consumption power will be recorded and tracked after shopping at the group-purchasing website. Many people claimed that they have received annoying phone calls from other similar companies after shopping online.

Finally, it is difficult to guarantee payment security. Payment of group-purchasing is usually online transactions through online banking, Alipay, and so on. With the development of mobile group-purchasing, payment from mobile phones client are more and more popular, and new payment are emerging, such as micro-message payment. How to protect the user's account security and the payment process security is still a big problem in the transaction process, which may seriously affect the development of the online grouppurchasing.

\section{Analysis on the issues and problems of online group- purchasing}

The group-purchasing, as a new kind of network consumption patterns, occupies a huge market but accompanies with issues and problems of failures, insecurities, etc. these issues and problems is closely related to the unclear marketing model, the indifference to internet security, the blocked channels of remedies for breach of contract, and the imperfect supervising and management system.

\subsection{The marketing model of group-purchasing is unclear}

The group-purchasing website has appeared over three years, turning the business model from attracting customer with advertisement and subsidy regardless of the cost to a more rational one. The main revenue of group-purchasing website at present comes from the commission from seller or bonus deducted a percentage from the sales volume. The classification of all group-purchasing websites is mainly limited to food, travelling, parent-child, shopping, and entertainment. Consumers can search information only through that classification and region classification. Moreover, the merchandise for group-purchasing is mainly restricted to food. By website's providing food packages and vouchers, Consumers can get price benefit. Because the industries of sellers the websites gathered are similar, and products provided are same and similar, the competitive advantages lost between websites. The tendency of unclear business model and the serious homogenization causes not only waste of network resources, but also cause reduction of consumers' interest, which directly result in the decline of sales volume. In the shopping process, group-purchasing websites receive consumers' fees in advance and provide every consumer a password as credential in consumption. When the merchants received and used the password, the websites will actually accept the fees and transfer the money left after deducting the commissions to merchants. But many dishonest businessmen usually imply to consumers that they can enjoy the same or more benefit without group-purchasing for the purpose to avoid paying the commission to group-purchasing website. The behavior that the merchants make use of the grouppurchasing website as an advertisement tool shows that the business and revenue model should be improved.

\subsection{The security of the group-purchasing websites is neglected}

The continuous leakage of consumers' personal information from websites and security incidents of online transactions may result from the ideologically indifference to the network security and technical protection for the website. There are two key causes as follows.

On the one hand, it is difficult to balance the payment security and efficiency. There are four basic steps to finish the online group-purchasing. That is, selecting items and 
submitting orders; choosing payment method to complete the payment; receiving Group Shopping code and password; accepting group-purchasing products or enjoying services from merchants. The security risks behind the four steps lay in the payment process and the process between consumers' successful payment and actual consumption. The higher the security levels the lower efficiency of shopping process. Therefore, the fast-convenience payment becomes the first choice for many consumers. However, high security risk exists in this payment method. According to the features of the fastconvenience payment, the third party payment companies have the right to manage the payment process. That's to say, money can be directly transferred from the bank accounts of consumers without the passwords of the bank accounts. So the transaction will not be protected by bank. In addition, with the increase of mobile payment users, the ability of security protection has not kept up with its development. Security vulnerabilities of the smart phone is higher than the traditional PC, thus, the fast-convenience payment by mobile phone has more security threats. Finally, there is a time span between consumers' successful payment and the actual consumption when group-purchasing. If the purchasing information are leaked, and the products or services the consumer purchased are consumed by others during this time span, it is not easy for him to present evidences in his favor and recover actual damages.

On the other hand, the disclosure of consumers' privacy affects their confidence in group-purchasing. In February 2012 , it was found that the popular domestic group shopping program "most countrified group shopping program" has SQL injection vulnerabilities in some of its versions, which could lead to a large number of group-purchasing websites' databases being attacked by hackers and even lead to consumption credentials being disclosed. The "most countrified group shopping program" is a free, open source platform for group-purchasing system, covering more than thousand domestic group-purchasing websites, including many well-known large ones. Some security specialist indicated that by using the vulnerabilities of the "most countrified group shopping program", hackers can tamper with the grouppurchasing activities, commodity prices, orders, refund, shipping records and other important data, and attacking databases to steal users' registered email address and password. The vulnerabilities bring latent dangers to the users' information security. The threat of personal privacy disclosure damages the consumer confidence, which resulted in the declining reputation and reliability of the website, and disturbance to website operation.

\subsection{Remedy channels for breach of contract are impeded}

With the rising disputes on group-purchasing, there are more and more breaches of contracts. Some consumers complained their unequal treatment and merchants' poor service attitude to customers in group-purchasing consumption; many consumers admitted that they had encountered consumption trap and had to pay a lot hidden charges after group-purchasing consumption; some consumers found the goods received from group-purchasing often with wrong version, out of date or adulterated. How to safeguard their own legal rights and implement rights of relief and which department they can complain to after disputes occurred become difficult problems to consumers.

The first reason may be the unclear legal relationships among subjects of online group-purchasing. Three legal subjects involves in the transaction: seller, consumers and website. In the consumption process, consumers and seller form the sales contract relationship. But as a middleman, the group-purchasing website acts as a broker or an intermediate is not clear. The existing laws and rules have not directly show whether the legal action forms the brokerage contract or intermediation contract, which liability the website may take among the joint liability, share liability, complementary liability and others, what's the condition of the establishment and validity of the online contract, etc.If legal disputes occur between consumers and businesses, and businesses have closured or do not exist in real world, consumers can only seek to recover from group-purchasing website to protect their legal rights. But in the "Law on Protection of the Rights and Interests of Consumers" and "contract law" and other relevant laws, there is no direct regulation about online grouppurchasing. And this would produce certain obstacles for consumers to obtain the right remedy, and inhibit the development of online group-purchasing objectively.

The second reason may be the difficulties to preserve the digital evidence. After finishing the online group shopping, consumers do usually not preserve the orders, web promotions and other relevant information except the bank's transaction records and SMS sent by group-purchasing websites. The data are entirely in the hands of the websites. Once dispute occurs, the consumers will be at a disadvantage status that they are difficult to fix the digital evidences from the website. In addition, all the evidences in online group-purchasing are digital, the evidences itself are difficult to save and present for consumers.

\subsection{The vulnerabilities exists in the supervising and management system of online group-purchasing}

There is a close relationship among the high frequency and difficult resolution of online group-purchasing disputes and the poor supervising and management system.

First of all, the online group-purchasing lacks of specialized supervision. The main agencies of regulation on a group-purchasing website are the administrative authorities for industry and commerce. But these institutions are generally expost regulatory agencies according to consumers' feedback, which is difficult to play the role of supervision beforehand. The cost of building a group-purchasing website is low that it only needs about ten thousands RMB and several managers to start up a website. Only after a period of time of operation and the disputes occurred, did some group-purchasing websites find they have not registered and filed with the departments of commercial and industrial administration or authorized 
institutions. In addition to the vulnerabilities of regulation system to the websites, the supervision to the merchants is also missing. The group-purchasing websites does not examine the qualification of merchants cooperated with them in general. If the merchants in group-purchasing have no proof of qualifications or provide false proof to a website and the website does not earnestly implement examination, the consumers may suffer losses.

Second, it lacks special law to regulate the online grouppurchasing. The development of the online group-purchasing is getting better and better, but the relevant legal system has not kept pace with it. The state administration for industry and commerce released "the policy on strengthening the management of online group-purchasing" in 2012. Besides this, no special laws or rules regulate online group-purchasing. Disputes or crimes can only be handled according to similar situations in the relevant civil law or criminal law. So, it's vital to perfect the relevant laws and regulations for the improvement of online group-purchasing.

At last, the self-regulation of websites and businesses is not enough. Online group-purchasing website, when organizing businesses and consumers in group-purchasing activities, shouldn't consider commissions as the only goal, but should take its responsibility and show its joint liability clearly to consumers. It must play an important role on scrutinizing qualifications of the sellers and responding to the feedbacks of customers. Likewise, businessman should enhance the selfregulation by providing the same goods and services to online group-purchasing consumers and the common consumers.

\section{Countermeasures on promotion the wellbeing of online group-purchasing.}

\subsection{Cultivating the consumers' confidence in online group- purchasing}

Customers are unconfident about group-purchasing websites, because they are worried about the website security, payment safety and after-sale protection. Consequently, only by enhancing security protection mechanism, legal aid and commercial insurance system can we cultivate and enhance consumers' confidence in online group-purchasing

Firstly, diversified protection systems of information security should be provided. Information security involves not only technical issues, but also refers to law, management and so on. To guard against illegal behavior, the efforts of network security protection should be enhanced and daily management of information security should be intensified by means of increasing the severity of illegal behavior punishment, raising the cost of crime and delinquency, and improving the management measures. With the aid of diverse policies, it can protect information security of online group-purchasing so as to strengthen consumers' confidence and finally lead to the further growth of group-purchasing population.

Secondly, law aid mechanisms for consumers should be supplied. Since consumers' rights and interests are damaged frequently in group-buying, effective law aid mechanism is essential to protect the interest of the vulnerable group. Once a legal dispute happens between consumers and sellers, consumers need to expense a lot of human and financial resources to deal with it. Because the losses are not too much to every one customer, consumers tend to give up protecting their legal rights, which encourages businesses' infringement or breach of contract in some extents. Therefore, establishing an effective law aid system can provide ways for consumers to protect themselves, and also strengthen the supervision to merchants and websites, helping the regulation and development of the online group-purchasing.

Thirdly, commercial insurance policy should be introduced. To authentically realize the growth of consumers' confidence in online shopping, protection of consumer's practical interest from the prospective of economics should also be considered. If commercial insurance policy can be introduced, the protection of online payment and consumption processes will be strengthened greatly. Deducting a little money from the transaction to buy commercial insurance for consumers when shopping online, consumers will feel more secure and more confident to online group-purchasing.

\subsection{Innovating the marketing model of online group- purchasing}

Group-purchasing websites develop fleetly; thousands of websites are born in a short period of years in China. Meanwhile, the closure percentage of group-purchasing websites is high. One reason is that marketing patterns and the customer types of most websites are similar; the other reason is that the marketing models of existing websites still focus on venture capital investment pattern.

Through the venture capital investment-driven business model, group-purchasing websites can absorb a lot of venture funds in short period so that they can capture the market rapidly and amplify the market share. With the fierce competition among group-purchasing websites in recent years, this model would not continue in the long run.

Group-purchasing business should segment market, and then analyze themselves' strengths, weaknesses, opportunities and challenges, to try to find competitive revenue model which can provide profits or interests for merchants, consumers and website. It is also essential to cultivate customers' loyalty and improve the services quality of consumption.

\subsection{Perfecting related laws of online group-purchasing}

There are many new legal issues and problems in online group-purchasing. But it's still not clear that which law will be applicable for these. Currently, the relevant laws and regulations related to online group-purchasing are mainly administrative rules, of which the legal effect is low. Therefore, the related laws need to be improved constantly, especially the civil laws and economic laws. Only by perfecting the related laws, can online group-purchasing get a healthy development.

\subsection{Consummating supervision system of online group- purchasing}

Supervision is an important way to achieve the healthy 
development of online group-purchasing. Only by strengthening the supervising and management system on group-purchasing websites, merchants and consumers, can group-purchasing websites achieve development orderly when facing the complex market.

Firstly, the supervision of group-purchasing websites and platforms should be strengthened. Group-purchasing website is the main platform for businesses to advertisement and for customers to evaluation. Other potential consumers make a decision whether to purchase or not always based on these information. Some merchants make false advertisement, and some merchants even disguise as consumers so as to make bad evaluation to other merchants. These two behaviors will both affect customers' choices. Therefore, group-purchasing websites have the obligation and responsibility to supervise the information merchants or customers delivered.

Secondly, the supervision by industry should be strengthened. With the development of online grouppurchasing, there have been some self-regulatory organizations by industry. But these organizations neither cover all the websites, nor have legal enforceability. So self-regulation and supervision by industry of online group-purchasing should take more effective supervision means. For example, the industry association can certificate those group-purchasing with high credit a higher rank, and those complained constantly by consumers with a lower rank, which makes it more convenient for consumers to identify group-purchasing service levels.

Thirdly, the administrative supervision also should be strengthened. The administration for commerce and industry is the mainly administrative and supervising department on group-purchasing websites and businesses, but the particularity of websites make it difficult to manage and examine. It's necessary to make more efforts on administrative regulation. It also requires the department to raise the level of management and recruit more people who have internet and e-commerce knowledge to manage and regulate.

\subsection{Improving the technical support on security of online group-purchasing}

Security technology is the foundation of online grouppurchasing. Whether group-purchasing websites are safe or not, not only have an effect on consumers' money and privacy, but also on the positive image and market of the website. Only by strengthening the management of security technology on group-purchasing websites, adopting new information security technology, enhancing technical support of the online grouppurchasing security and reducing the incidence of hacker attacks, can websites provide a safe shopping environment.
With regard to payment security, new payment method should be implemented to meet the demands of both security and efficiency.

By a variety of ways such as law, management and technology, we can make the group-purchasing more reliable and make more would-be customers to choose online grouppurchasing and maximize the interests of all parties.

\section{Acknowledgments}

This paper is sponsored by the Shanghai municipal education commission key discipline (forensic science, J51102), national social science fund youth project (12CFX056, 13CFX054), and Shanghai local colleges and universities academic of social science cultivation plan.

\section{References}

[1] The State Administration for Industry and Commerce. "the policy on strengthening the management of online group-purchasing". http://www.saic.gov.cn/zwgk/zyfb/zjwj/scgfgls/201203/t20120314_124 902.html.

[2] Wang Feixia, Zhang ying. Analysis on the blow out of online grouppurchasing in the day "double 11". The news sentinel, no.2, pp76 79, 2013.M. King and B. Zhu, "Gaming strategies," in Path Planning to the West, vol. II, S. Tang and M. King, Eds. Xian: Jiaoda Press, 1998, pp. 158-176.

[3] China e-business research center. Report on the market monitoring data of online group-purchasing in 2013(the first half). http://www.100ec.cn/

[4] Xinhua net. Concerning the closures of group-purchasing website. http://news.xinhuanet.com/fortune/2013-08/01/c_116763481.htm.

[5] China e-business research center. Report on investigation of online group-purchasing industry in 2013. http://www.100ec.cn/

[6] China e-business research center. Report on the market monitoring data of online group-purchasing in 2012. http://www.100ec.cn/

[7] China e-business research center. Report on the market monitoring data of online group-purchasing in 2013(the first half). http://www.100ec.cn/J.-G. Lu, "Title of paper with only the first word capitalized," J. Name Stand. Abbrev., in press.

[8] China Webmaster. Oldland v. 24quan.com, the first litigation of grouppurchasing in Beijing. http://www.chinaz.com/biz/2011/1125/222693.shtml.

[9] Dayoo website. Jingdong cancels 1 yuan group-purchasing activity of Shaoxing tour: hundreds of customers attend the rights activities. http://news.dayoo.com/finance/201203/22/53869_22789846.htm.

[10] Tencent website. Group-purchasing cooperation arouses disputes: Meituan CEO will sue DQ. http://finance.qq.com/a/20110307/001064.htm.

[11] Jinghua net. Thousands members' privacy information of a grouppurchasing website disclosed. http://epaper.jinghua.cn/html/201308/01/content_14683.htm.M. Young, The Technical Writer's Handbook, Mill Valley, CA: University Science, 1989.

[12] Longhoo website. Fast-convenience payment becomes a new target for liars, security vulnerabilities of Alipay frequently occurs. http://finance.longhoo.net/2013-02/03/content_10484165.htm.

[13] Tencent website. Security vulnerabilities was found in "most countrified group shopping program". http://tech.qq.com/a/20120224/000469.htm. 